\title{
Universities accused of inefficient book-keeping
}

\section{David Dickson reports on continued skirmishing between US politicians, administrators and scientists over use of research funds}

Government auditors have accused Harvard University of claiming over \$2 million in "inappropriate" costs charged to federal research projects carried out by the university's School of Public Health between 1975 and 1977. They further state that, on the basis of sample studies of cost transfers, "we cannot attest to the proprietary of about $\$ 15$ million charged to federal grants" during this period, out of a total of $\$ 37.1$ million audited.

These conclusions have emerged from an audit carried out by the Department of Health, Education and Welfare following allegations that the university was violating agreed procedures for claiming research costs from the federal government. The university has already announced its intention to challenge the draft audit, which has not yet been publicly released; but the incident has fuelled further skirmishing between politicians, administrators and scientists over how universities should account for their use of public research funds.

The politicians insist that, since the funds come from the public purse and their expenditure has been decided by Congress, then it should be demonstrated that they are spent in the way that Congress intended. But the universities claim that too much time spent accounting for the use of funds can hamper the research scientist and may ultimately undercut the value of the research itself.

Allegations about Harvard's misuse of funds were first made by Dr Phin Cohen, previously a research worker in the School of Public Health, in 1975. He repeated the allegations - and provided details of DHEW's draft audit - at a hearing held recently by the intergovernmental relations and human resources subcommittee of the House committee on government operations.

A particular focus of the hearing was a report just completed by the General Accounting Office claiming that many audits of university research expenditures were "not as effective as they could be". In some cases, inadequate university accounting systems meant federal auditors were unable to give an opinion on the allowability of costs charged to federal grants and contracts.

The GAO points out, for example, that of $\$ 1.2$ billion in research grants and contracts audited by DHEW in 1977 , over a third was not properly documented. In one university, $\$ 53.7$ million of personal service costs, out of $\$ 111$ million charged to federal grants and contracts over a three year period, could not be adequately supported, since they were based on budget estimates rather than actual certified costs.

The GAO was also critical of some of the
DHEW's audit operations. Department officials, however, while accepting some weaknesses in auditing procedures, placed considerable blame on the universities which, they said, frequently failed to keep accounts in a form which meets federal standards. Mr Edward Stepnick, assistant inspector general for auditing at DHEW said compliance with auditing requirements was non-existent or inadequate at about $70 \%$ of the major colleges and universities audited.

Universities, in turn, continue to charge that the accounting requirements placed on them are often unreasonable and unrealistic. Their accounting is in fact, much better than they are being given credit for, according to Dr Max Binkley, vice-president for finance at Colorado State University. Publicity alleging scandal and malfeasance gave the public the wrong impression of issues which principally involved questions of accounting precision and documentation, he said. "A scientist is deeply engrossed in the pursuit of new knowledge in his or her field of specialisation, with the result that efforts towards precision in costing are disruptive and burdensome and constitute an impediment to the accomplishment of the ultimate objective."

All sides hope that the situation will be improved by the recent revision of Circular A-21, a document published by the Office of Management and Budget laying down guidelines for charging the direct and indirect costs of research. Considerable

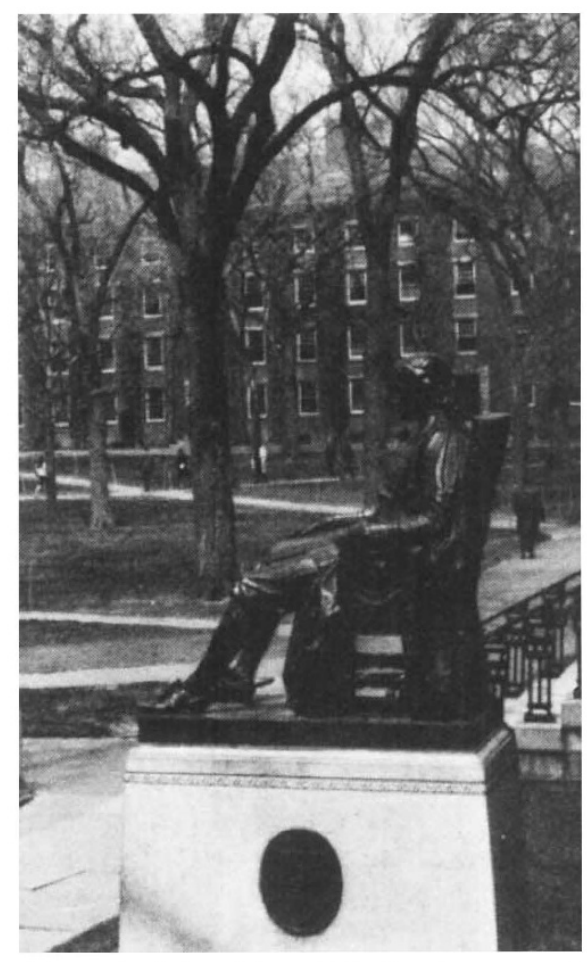

Harvard: sitting tight and challenging the audit differences still remain over costing principles, - particularly the way that research workers should account for the time spent on various projects - "the toughest and longest standing problem revealed by our audits" according to Mr Stepnick.

Under existing accounting rules, scientists receiving federal grant money have to report regularly on the way they have spent the previous month or two weeks. Under the revised A-21, a university can opt for a monitored workload system, in which the distribution of time is agreed before the project begins. Changes in the agreed workload have to be reported, and "significant" changes entered in the accounts. Mr Bowman Cutter, director of the budget in OMB, said this was a reasonable compromise, reached after considerable negotiation, between the demands of accountability and the flexibility needed by universities to administer research in an effective way.

University representatives, however, disagreed. They had been pressing that only significant changes in workload need be reported. "Insignificant changes to workload occur daily, perhaps even hourly," Dr Brinkley said. "Having to note all minor variations in activity was virtually impossible." He told the subcommittee that OMB's decision meant most institutions would not now adopt the monitored workload system, but opt instead for the personnel activity reporting, with which neither the government nor the universities were satisfied. "The overzealous attempt by the government to refine the system has evidently brought its defeat", he said.

Dr Thomas A. Bartlett, president of the Association of American Universities, told the subcommittee that his association wanted a number of changes in federal accounting rules. These included adoption of a monitored workload system "as a fully acceptable means for documenting effort", and grouping related grants for the purposes of administration. On the first, he echoed Dr Binkley's complaints that restrictions demanded by OMB in the revised Circular A-21 will probably deter widespread use of the system.

Dr Cohen suggested some more radical changes. He first described to the subcommittee how concern at the way university administrators had controlled the use of his grant money had led him to report the matter to the National Institutes of Health; following an investigation, the university had agreed to repay $\$ 132,350$. Dr Cohen suggested the "reenfranchisement" of principal investigators, who would sign all time and effort reports, salary certifications and reports of expenditure, rather than delegating these functions to university officials. 